\title{
The popularity of the 5-and 6-component combination vaccines among infants' parents in a selected Primary Health Care Clinic
}

\section{Popularność pięcio- i szcześcioskładnikowych wysokoskojarzonych szczepionek wśród rodziców niemowląt w wybranej placówce Podstawowej Opieki Zdrowotnej}

\author{
Marek Wojczyk ${ }^{1, A-D \oplus}$, Marcelina Anna Podstawa ${ }^{2, C-F \oplus}$ \\ 1 Doctoral Studies, Department of Medical Science, Medical University of Silesia, Katowice, Poland \\ 2 Department of Clinical Nursing, Nursing and Midwifery Institute, Collegium Medium, Faculty of Health Sciences, \\ Jagiellonian University, Kraków, Poland \\ A - Research concept and design, B - Collection and/or assembly of data, C - Data analysis and interpretation, \\ $D$ - Writing the article, $E$ - Critical revision of the article, $F$ - Final approval of article \\ Wojczyk M, Podstawa MA. The popularity of the 5- and 6-component combination vaccines among infants' parents in a selected Primary \\ Health Care Clinic. Med Srod. 2020; 23(1-4): 1-4. doi: 10.26444/ms/136402
}

\section{Abstract}

Introduction. Vaccination, one of the highest achievements of medicine, has contributed to a significant reduction of infectious diseases. According to the current vaccination calendar in Poland, parents have the possibility to choose a free cost classic (DTP, polio, HBV) or non-refundable 5- or 6-component combination vaccine.

Objective. The aim of the study was to assess the popularity of the 5- and 6-component combination vaccines in years 2010-2019 among infants s parents starting a mandatory series of vaccination in a selected Primary Health Care Clinic.

Materials and method. The study was conducted at the Med-All Medical Centre in Kraków which provided a Protective Vaccination Programme including 1,108 immunization cards of children born between 2010-2019, most of whom (98.5\%) lived in Kraków. Analysis of medical records was used in the retrospective ecological study; data analysis by MS Excel (Microsoft) and PQStatSoft. Significance level was setatnp $<0.05$. Results. From 2010-2016, the 5-component combination vaccine was the most popular choice by parents for their infants. During the study period, use of the 5-component combination vaccine decreased $(p=0.017)$. From 2017, the 6-component vaccine was the most popular, and its usage increased with time, with a strong statistically significance $(p=0.005)$. However, in 2019, there occurred the biggest percentage of unvaccinated infants.

Conclusions. Despite the costs, in 2010-2016, the most popular vaccine for infants was the 5 -component high-combination vaccine. Since 2017, the 6-component vaccine has gained the greatest popularity.

\section{Key words}

infant, vaccination calendar, 5-component combination vaccine, 6-component combination vaccine

\footnotetext{
Address for correspondence: Marcelina Anna Podstawa, Department of Clinica Nursing, Nursing and Midwifery Institute, Collegium Medicum Faculty of Health Sciences, Jagiellonian University, Kraków, Poland

E-mail: marcelina.podstawa@uj.edu.pl

Received: 06.04.2021; accepted: 05.05.2021
}

\section{Streszczenie}

Wprowadzenie i cel pracy. Zdobycz medycyny, jaką są szczepienia ochronne, przyczyniła się do ograniczenia występowania chorób zakaźnych. Aktualny kalendarz szczepień przewiduje możliwośćzdecydowania przez rodziców o programie szczepień dla ich dziecka. Wybór może zostać dokonany między refundowanymi szczepionkami klasycznymi (DTP, polio, HBV), a pełnopłatną 5- lub 6- składnikową szczepionką wysokoskojarzoną. Celem badań było zbadanie popularności 5- i 6-walentnej wysokoskojarzonej szczepionki na przestrzeni lat 2010-2019 wśród rodziców niemowląt rozpoczynających cykl obowiązkowych szczepień ochronnych na przykładzie wybranej placówki Podstawowej Opieki Zdrowotnej.

Materiałi metody. Badanie przeprowadzono w centrum medycznym All-med w Krakowie, realizującym Pogram Szczepień Ochronnych. Przeanalizowano 1108 kart uodpornienia dzieci urodzonych w latach 2010-2019. Do zrealizowania retrospektywnego badania ekologicznego użyto metody analizy dokumentacji medycznej. Analizę statystyczną przeprowadzono z wykorzystaniem programów MS Exel (Microsoft) oraz PQStat Soft. Przyjęto poziom istotności statystycznej $p<0,05$.

Wyniki. Od 2010 do 2016 roku szczepionką najczęściej wybieraną dla niemowląt była 5-składnikowa szczepionka wysokoskojarzona. W badanym okresie stosowanie 5-składnikowej szczepionki zmniejszało się wraz z upływem lat $(p=0,017)$. Od 2017 roku najpopularniejszą szczepionką była 6 -składnikowa szczepionka wysokoskojarzona, a jej użycie wzrastało z biegiem lat, przy czym odnotowano silnązależność statystyczną $(p=0,005)$. W 2019 roku odsetek nieszczepionych niemowląt był największy.

Wnioski. Na przestrzeni lat 2010-2016, pomimo konieczności poniesienia kosztów przez rodziców niemowląt, szczepionką dla niemowląt najczęściej wybieraną przez rodziców była 5-składnikowa szczepionka wysokoskojarzona. Od 2017 roku większą popularność zyskiwała szczepionka 6-składnikowa.

\section{Słowa kluczowe}

niemowlę, kalendarz szczepień, 5-walentna szczepionka wysokoskojarzona, 6-walentna szczepionka wysokoskojarzona 


\section{INTRODUCTION}

Vaccination is one of the greatest achievements of medicine and has undeniably contributed to a significant reduction in deaths caused by infectious diseases. Most countries introduced compulsory preventive vaccination programmes against diseases which for years had been decimating the population. Vaccinations show a dual protective effect for the individual and the health of the population $[1,2]$. Individual protection refers to preventing morbidity and reducing complications. The effect on the whole population is related to the stopping of potential transmission of the disease to other members of the population who are more susceptible to this kind of pathogen. An optimal population resistance is reached when about $90.0 \%$ of the population is vaccinated against certain diseases $[1,2]$.

The possibility for parents to choose different types of vaccines depends on the moment of licensing the vaccine, which is related to making it available for sale. For 5component vaccines, an example of a marketing approval year is 2001 for Infanrix IPV + Hib and 2003 for Pentaxim. Marketing approval for 6-in-1 vaccines was started in 2012 for Hexaxim [3], 2013 for Hexacima [4] and Hexyon [5], ande in 2016, marketing approval was granted for Vaxelis [6]. In the first years after the start of distribution, during the study period there arose problems with the availability of multi-component vaccines. Producers deliveed them first to countries where they had concluded government agreements, and in consequence, combined vaccines did not reach Poland until the second round.

According to the current vaccination calendar, which sets the rules for immunizing children in Poland, vaccinations against the following diseases are mandatory: tuberculosis, hepatitis $\mathrm{B}$, diphtheria, tetanus, pertussi, acute common paralysis (poliomyelitis), haemophilus influenzae, pneumococcus, measles, mumps and rubella. The first vaccination has to be given in the hospital during the first days of life of the infant. After the 6th week of life, the parents have to decide about their choice of vaccination programme for their child in Primary Health Care Clinic. The choice can be made between the standard vaccines (DTP, polio, HBV) and a 5- or 6-component combination vaccine. Multicomponent vaccines contain antigens of: diphtheria, tetanus, pertussis, polio, haemophilus influenzae, and additionally recombinant $\mathrm{HBV}$ antigens in a 6 -component vaccine [7, 8].The combination vaccine programme is presented in the vaccination calendar as an alternative scheme (Tab. 1).

The most important advantages of using the 5- or 6-component products are:

- a smaller number of injections, in the case of using a 5-component vaccine the number of injections decreases by 7 , and for a 6-component vaccine by 9 [9];

- lower risk of infection due to the significantly smaller number of injections needed;

- smaller quantities of preservatives in smaller volume [8];

- elimination of the thiomersal, an organomercury compound, which is controversial due to its potential damage to health [10];

- lower risk of adverse post-vaccination reactions associated with the pertussis component.

High combination vaccines contain between $1-5$ pertussis antigens instead of whole killed bacteria, as in the DTP vaccine $[8,11]$. Despite the advantages, the greatest deterrent to using combination vaccines seems to be their price. In Poland, the cost is not refundable by the State [10]. For this reason, parents have to choose between a free of charge programme, standard vaccines or the expensive 5- or 6component vaccines requiring an extra payment.

The whole-cell pertussis antigen vaccine is not recommended for children in a high risk group, e.g. children born before 37 weeks or with a birth weight below 2,000g. In such exceptional cases, a cost-free 5-component vaccine is provided $[7,8]$.

Table 1. Vaccine calendar with alternative multicomponent scheme

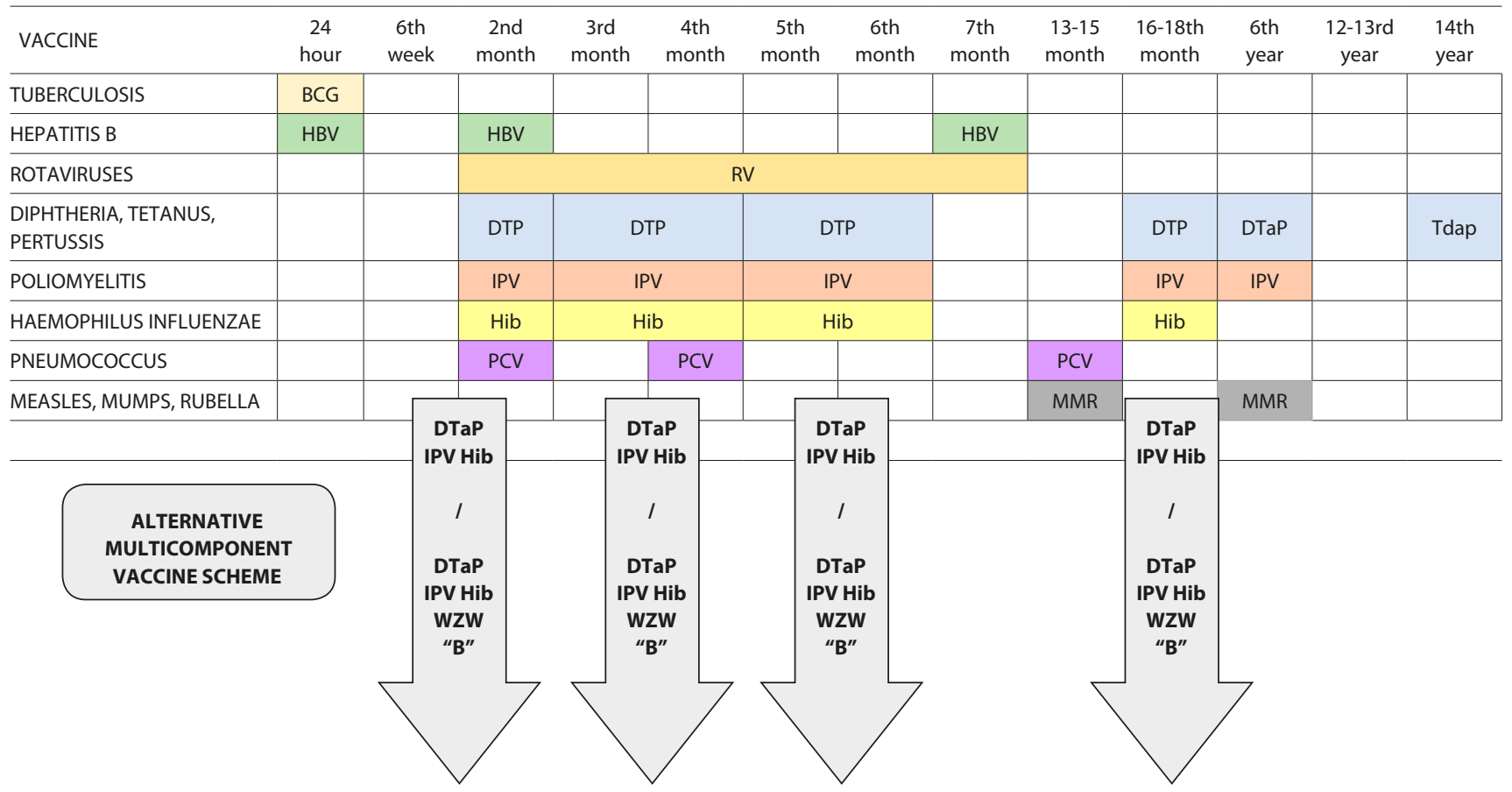




\section{OBJECTIVE}

The aim of this study was to investigate the popularity of the 5- or 6-component combination vaccines among parents of infants starting a mandatory vaccination series in a selected Primary Health Care clinic.

\section{MATERIALS AND METHOD}

The study was conducted at the Med-All Medical Centre in Kraków which provides a Primary Health Care service and undertakes a Protective Vaccination Programme. Analysis was performed of 1,108 immunization cards of children born between 2010 and the end of October 2019. The cards included information about the type of programme chosen by the parents. Infants born in November and December 2019, and did not start the vaccination programme in 2020 were not included. When animmunization card showed that a child had started a vaccination course with one classic vaccine, but subsequently received 3 doses of a 5-component vaccine, this choice was credited to the 5-component programme. The other types of vaccine were accredited similarly. The obtained data was subjected to statistical analysis in MS Excel (Microsoft) and PQStat Soft. Nominal data were examined with the chi-square test and significance level set at $\mathrm{p}<0.05$.

\section{RESULTS}

The study included the immunization cards of 1,108 children, the majority of whom (98.5\%) lived in Kraków. Among these children, there were 26 (2.35\%) who did not start a preventive vaccination course. The reasons for this were not analysed. The study showed that from 2010-2016, the 5-component combination vaccine was the most popular choice by parents for their infants. Although 2010 was the year with the greatest popularity $(72.32 \%)$, vaccination in the classic programme was at the lowest level (9.82\%). In 2011, the highest frequency occurred of using the classic vaccine (31.33\%); from 2016, popularity of 5-component vaccine gradually decreased, and from 2017, the 6-component vaccine the one most preferred. The peak of popularity occurred in 2018, when up to $57.15 \%$ parents chose this type of vaccine for their child (Fig. 1).

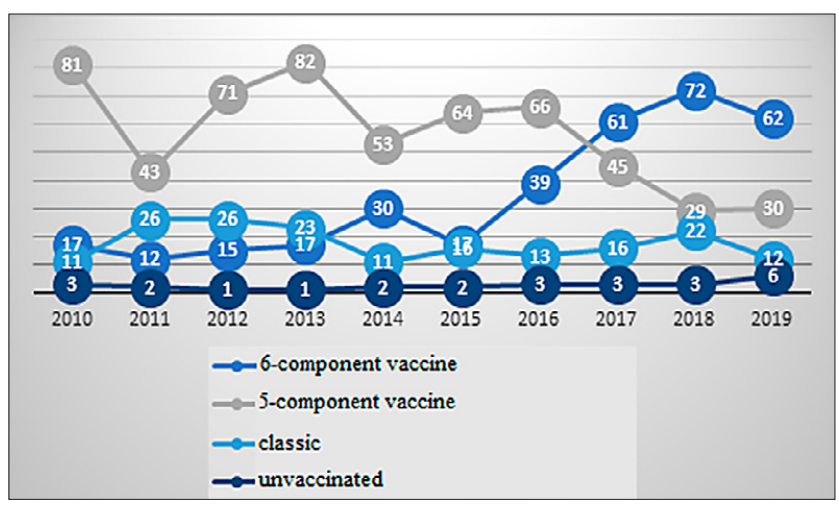

Figure 1. The number of vaccine types administered among children born during the study period presented in the line graph

During the study period, the 5-component vaccine become less and less popular and the usage decreased with years $(\mathrm{r}=-0.6 ; \mathrm{p}=0.017)$. In 2015 , the 6 -component vaccine was released on a larger scale, which was also associated with the beginning of an increase in its selectivity. The usage of 6-component vaccine increased with years, with a strong statistical significance $(r=0.689 ; \mathrm{p}=0.005)$. However, the percentage of parents choosing the classic vaccination programme did not correlate with years $(\mathrm{p}=0.601)$ (Tab. 2$)$, and the average number of children vaccinated was stable during the 10 -year period at $16 \%(\mathrm{SD}=5 \%)$. During the 10 year analysis, the number of children who did not start any protective vaccinations did not increase $(\mathrm{p}=0.601)$ and was between $1 \%-3 \%$. The exception was the year 2019, when there occurred the highest percentage of unvaccinated children (5.45\%) (Tab. 2).

Table 2. Kendall's tau correlation coefficients for the percentage of children vaccinated with each type of vaccine in the analyzed period

\begin{tabular}{lcc}
\hline Type of vaccine (variable) & Kendall's tau & p-value \\
\hline 6-component vaccine & 0.689 & 0.005 \\
\hline 5-component vaccine & -0.6 & 0.017 \\
\hline classic & -0.244 & 0.381 \\
\hline unvaccinated & 0.156 & 0.601 \\
\hline
\end{tabular}

\section{DISCUSSION}

Multi-component vaccines are a way to reduce the child `s suffering associated with the number of injections. This is the most important reason for parents deciding to buy the 5- or 6-component vaccines. A study of Szymoniak et al. shows that $52 \%$ of Polish parents chose non-reimbursed vaccines instead of those free of charge [12]. Although most European countries finance their compulsory vaccination programmes, Poland is one of the few countries where the 5- or 6 -component vaccines are not free $[13,14]$. The current study shows that the popularity of multi-component vaccines, on average, was $81 \%$. In the study of Pieszka et al. the percentage of parents choosing high-associated vaccines was $64 \%$, of which $78 \%$ of parents chose a 5 -component vaccine and $22 \%$ a 6 -component vaccine [15]. Additionally, in the Nitsch Osuch et al. study, $17.6 \%$ of parents chose the 5-component vaccine and $10.8 \%$ the 6 - component vaccine [16]. However, a different trend was noted in a study by Pomian-Osiak et al. in which the most popular was a 6-component vaccine (53\%), and only $23 \%$ of parents chose a 5 -component product [17]. All the studies, however, showed a high popularity for choosing multi-component vaccines. Pieszka's study, which confirms the claims in the current study, paid attention to the reduction in the number of injections, lower stress experience, and high level of vaccine safety. The necessity of paying for the multi-component vaccine, however, was indicated as a disadvantage [15]. This study corresponds with that by Kędzierska et al., which claims that, despite the additional costs, parents extended the compulsory vaccination calendar with optional vaccination [18]. Hubicki observed that the major factor behind opting for the classical vaccination programme was socioeiconomic [19]. These studies showed a strong positive correlation between the parents' economic situation and the use of recommended vaccinations.

The stable use of classic vaccines, as well as a significant increase in the amount of parents who did not vaccinate 
their children in 2019, could have been be caused by fear of the multi-component vaccine content. Some parents did not want to choose vaccine with higher number of antigens administered simultaneously. It is correlated with Pieszka’s study in which $15.9 \%$ of the parents surveyed believed that a high combination vaccine could be harmful to a child's health [15]. In the scheme with the use of classic vaccines, subsequent vaccines can be administered individually, which is associated with fewer antigens administered to the child during one vaccination visit. Gańczak et al. believes that the most important role with making decisions about the type of vaccine is knowledge provided by medical personnel whom parents meet at the medical centre [20]. Furthermore, in the Pieszka study, 94\% of parents received satisfactory information about the vaccines during their first visit [15]. High combination vaccines are not only popular among parents who want to avoid suffering in their child. Compared to the classical vaccination, the multi-component version have proved to be safer, while ensuring proper immunity for the child, which could be the reason for more countries deciding to fund them from State budgets [21].

\section{CONCLUSIONS}

Multi-component vaccines were the most popular among infants' parents, despite the necessity to pay and the lack of refunds. Between 2010-2016, during which time the 5 -component vaccine was particularly popular, in 2017 it was been replaced by the 6-component vaccine. In the analyzed period, a similar percentage of parents chose the classic vaccine. The fact that the percentage of vaccinated children was the lowest in 2019 should be the subject of further, more detailed research to clarify the phenomenon.

\section{REFERENCES}

1.Gołąb J, Jakóbisiak M, Lasek W, et al. Immunologia. Warszawa: Wydawnictwo naukowe PWN; 2017. p. 312-326.

2. Male D, Brostoff J, Roth D B, et al. Immunologia. Warszawa: Elsevier Urban \& Partner; 2008. p. 325-339.

3. European Medicines Agency gives first opinion for a vaccine for use outside the EU. European Medicines Agency (EMA). https://www.ema. europa.eu/en/news/european-medicines-agency-gives-first-opinionvaccine-use-outside-eu [accessed 29.04.2021].
4.Hexacima EPAR. European Medicines Agency (EMA). https://www. ema.europa.eu/en/medicines/human/EPAR/hexacima [accessed 29.04.2021].

5. Hexyon EPAR. European Medicines Agency (EMA). https://www.ema. europa.eu/en/medicines/human/EPAR/hexyon [accessed 29.04.2021].

6. Vaxelis EPAR. European Medicines Agency (EMA). https://www.ema. europa.eu/en/medicines/human/EPAR/vaxelis [accessed 29.04.2021].

7. Program Szczepień Ochronnych w 2020 roku. https://szczepienia.pzh. gov.pl... [accessed 10.02.2020].

8. Wysocki J, Czajka H. Szczepienia w pytaniach i odpowiedziach. Kraków: Help-Med; 2018. p. 133-150.

9. Dolhain J, Janssens W, Sohn W-Y, et al. Integration of hexavalent diphtheria, tetanus, acellular pertussis, hepatitis B virus, inactivated poliomyelitis and Haemophilus influenzae type b conjugate vaccine within existing national recommendations following a birth dose of monovalent hepatitis B virus vaccine: results of a systematic review in the Asia Pacific region. Expert Rev Vaccines 2019; 18: 921-933.

10. Kramarz P, Pędziński B, Giesecke J. Tiomersal jako składnik szczepionek. Aktualny stan wiedzy. Med Prakt Pediatr. 2010; 1: 5-12, 7.

11. Zawadka M, Lutyńska A. Immunogenność i odczynowość bezkomórkowych szczepionek przeciw krztuścowi przeznaczonych dla młodzieży i osób dorosłych. Przegl Epidemiol. 2012; 66: 99-105.

12. Szymoniak K, Cholewa D, Fryc D, et al. Opinia rodziców na temat odmowy wykonania szczepień ochronnych u dzieci. Piel Pol. 2020; 77 (3): 159-165.

13. Koperny M, Kargul A, Seweryn M, et al. The prevalence of combination vaccines for children in Europe. Analysis of the availability and funding. JHPOR 2014; 2: 18-31.

14. Monge S, Hahné S J, de Melker H E, et al. Effectiveness of the DTPaHBV-IPV/Hib vaccine against invasive Haemophilus influenzae type b disease in the Netherlands (2003-16): a casecontrol study. The Lancet Inf Dis. 2018; 18: 749-757.

15. Pieszka M, Waksmańska W, Woś H. Wiedza rodziców dzieci do drugiego roku życia na temat szczepień ochronnych. Med Og Nauk Zdr. 2016; 22: 221-226.

16. Nitsch-Osuch A, Kozerska A, Topczewska-Cabanek A, et al. Realization of immunization schedule with recommended vaccines among children from one general practice. Fam Med Prim Care Rev. 2012; 14: 410-413.

17. Pomian- Osiak A, Owłasiuk A, Gryko A, et al. Vaccination of children at the age of $0-2$ with combination and recommended vaccines assessment of the frequency of use and the knowledge of parents. Probl Med Rodz. 2014; 3: 18-27.

18. Kędzierska A K. Realizacja szczepień ochronnych u dzieci do drugiego roku życia. Pielęg Pol. 2019; 73: 252-257.

19. Hubicki L, Czech E, Kowalska M, et al. Szczepienia ochronne dzieci $\mathrm{w}$ rodzinach o różnym stanie społecznoekonomicznym w Bytomiu. Przegl Epidemiol. 2004; 58: 713-723.

20. Gańczak M, Dmytrzyk-Daniłów G, Karakiewicz B, et al. Determinants influencing selfpaid vaccination coverage, in $0-5$ years old Polish children. Vaccine. 2013; 31: 5687-5692.

21. Obando-Pacheco P, Rivero-Calle I, Raguindin PF, et al. DTaP5-HBVIPV-Hib paediatric hexavalent combination vaccine for use in children from 6 weeks through to 4 years of age. Expert Rev Vaccines. 2019; 18 : 1115-1126. 